\title{
Heat Release Rates of Fully-developed Fires in Railcars
}

\author{
BRIAN LATTIMER and CRAIG BEYLER \\ Hughes Associates, Inc. \\ 3610 Commerce Drive, Suite 817 \\ Baltimore, Maryland 21227 USA
}

\begin{abstract}
A post-flashover fire model was used to predict the heat release rate of fully-developed fires inside of intercity and subway type railcars with polycarbonate windows. Peak heat release rates ranged from 14-41 MW and were sensitive to the initial number of doors open, time at which the polycarbonate windows fell out, and fire properties of interior finish materials. In some cases, the predicted heat release rate increased by 3-27 MW when the windows fell out. The magnitude of this increase was dependent on whether sufficient fuel was available to support the larger fire.
\end{abstract}

KEYWORDS: heat release rate, post-flashover fires, railcars

\section{NOMENCLATURE LISTING}

\begin{tabular}{|c|c|c|c|}
\hline$A$ & area $\left(\mathrm{m}^{2}\right)$ & $\varepsilon$ & emissivity (- -) \\
\hline C & $\begin{array}{l}\text { boundary specific heat capacity } \\
\left(\mathrm{kJ} / \mathrm{kg}^{\circ}{ }^{\circ} \mathrm{C}\right)\end{array}$ & $\sigma$ & $\begin{array}{l}\text { Stefan-Boltzman constant } \\
\left(5.67 \times 10^{-11} \mathrm{~kW} / \mathrm{m}^{4}-\mathrm{K}\right)\end{array}$ \\
\hline$C_{p}$ & gas specific heat capacity $\left(\mathrm{kJ} / \mathrm{kg}^{\circ}{ }^{\circ} \mathrm{C}\right)$ & \multicolumn{2}{|c|}{ Subscripts } \\
\hline$f$ & combustible fraction (- -) & air & air \\
\hline$h$ & enthalpy (kJ/kg) & bound & compartment boundaries \\
\hline$h_{\text {conv }}$ & heat transfer coefficient $\left(\mathrm{kW} / \mathrm{m}^{2}-^{\circ} \mathrm{C}\right)$ & $f$ & fuel \\
\hline$\Delta h_{g}$ & heat of gasification $(\mathrm{kJ} / \mathrm{kg})$ & $f l$ & flame \\
\hline$\Delta H_{c}$ & heat of combustion (kJ/kg) & gas & compartment gases \\
\hline$k$ & $\begin{array}{l}\text { compartment boundary thermal } \\
\text { conductivity }\left(\mathrm{kW} / \mathrm{m}^{\circ}{ }^{\circ} \mathrm{C}\right)\end{array}$ & $h$ & heater \\
\hline$\dot{m}$ & mass flow rate $(\mathrm{kg} / \mathrm{s})$ & $h f g$ & heat flux gauge \\
\hline$q$ & heat $(\mathrm{kW})$ & $i$ & inflow \\
\hline$Q$ & heat release rate in compartment $(\mathrm{kW})$ & $j$ & interior finish material \\
\hline$Q_{\text {total }}$ & total heat release rate $(\mathrm{kW})$ & $n$ & $\begin{array}{l}\text { total number of interior } \\
\text { finish materials }\end{array}$ \\
\hline $\bar{Q}^{\prime \prime}$ & $\begin{array}{l}\text { average heat release rate per unit area } \\
\left(\mathrm{kW} / \mathrm{m}^{2}\right)\end{array}$ & net & net into surface \\
\hline$q^{\prime \prime}$ & heat flux $\left(\mathrm{kW} / \mathrm{m}^{2}\right)$ & $o$ & outflow \\
\hline$r$ & stoichiometric fuel-to-air ratio & pyrol & surface during pyrolysis \\
\hline$t$ & time $(\mathrm{s})$ & $r r$ & re-radiation \\
\hline$T$ & gas temperature $\left({ }^{\circ} \mathrm{C}\right.$ or $\left.\mathrm{K}\right)$ & ref & reference value (273 K) \\
\hline Y & mass fraction & $s$ & material surface \\
\hline Greek & & ss & surface at steady state \\
\hline$\chi$ & combustion efficiency (- -) & vent & ventilation opening \\
\hline
\end{tabular}




\section{INTRODUCTION}

Mass transit systems are becoming more numerous throughout the world. In many of these systems, the railcars operate in underground tunnels and stations. In accordance with NFPA 130 "Standard for Fixed Guideway Transit and Passenger Rail Systems" [1], these stations and tunnels need emergency ventilation to ensure that passengers and crew can safely evacuate these areas to a point of safety. A fire involving the railcar is one of the worst-case scenarios considered in the design of the emergency ventilation system. As a result, the heat release rate of the railcar fire is an input needed for the design of the emergency ventilation system.

Data on fully-developed fires inside of actual railcars is limited; however, there have been some large-scale tests conducted on railcars inside tunnels to support tunnel design projects [2-5]. A detailed description of the tests is provided in Ref. [5]. The heat release rates $[2,3,5]$ and gas temperatures $[4,5]$ were measured for an aluminum exterior shell subway railcar with internal dimensions of $18.0 \mathrm{~m}$ long, $2.8 \mathrm{~m}$ high, $3.0 \mathrm{~m}$ wide and two different intercity railcars both with steel exterior shells and internal dimensions of $26.1 \mathrm{~m}$ long, $2.4 \mathrm{~m}$ high, $2.9 \mathrm{~m}$ wide. The subway railcar and intercity IC-train contained older interior finish materials, while the intercity ICE-train contained newer interior finish materials. All railcars had glass windows.

Initiating fires in the tests were pans of isopropanol located at one end of the railcar. Prior to ignition, windows and sometimes doors were opened to allow air to enter into the railcar. The measured heat release rates and gas temperatures near the ceiling are provided in Fig. 1. The subway railcar fire had a peak heat release rate of $35 \mathrm{MW}$, while the longer intercity railcars had peak heat release rates of 13-20 MW. The IC-train with older interior finish materials had a lower heat release rate than the ICE-train. Figure 1b contains gas temperatures $0.020 \mathrm{~m}$ below the ceiling inside these three railcars and inside a $13.8 \mathrm{~m}$ long subway car with a steel exterior shell. Temperatures during the fullydeveloped fires ranged from $400-900^{\circ} \mathrm{C}$. Shorter subway railcars were measured to have uniform temperatures along the length, while longer railcars had large temperature changes along the railcar length [5]. This could be due to the initiating fire and initial ventilation openings being located at one end of the railcar and the failure times of the windows during the fire. Windows were heard breaking as early as 2 minutes into the test

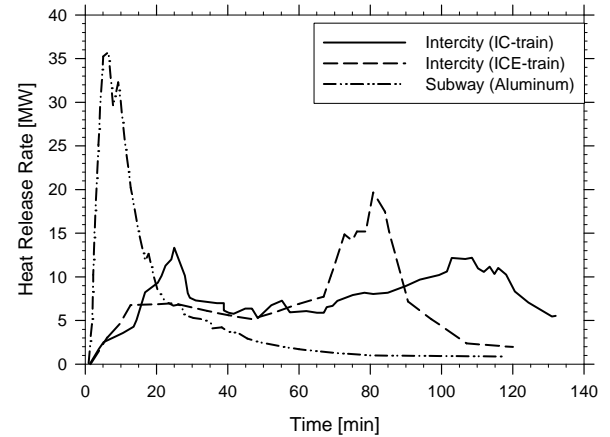

(a)

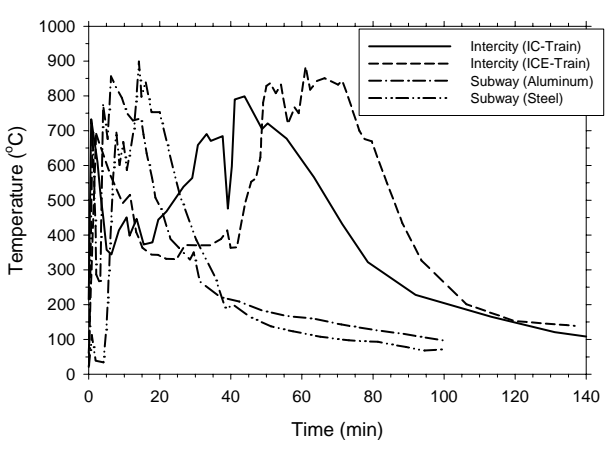

(b)

Fig. 1. Large-scale railcar test data [5], (a) heat release rate and (b) gas temperature. 
and as late as 42 minutes (Test F51), but in all cases all windows were blown out at the end of the test. In some tests, sounds of shattering windows did correspond with abrupt changes in temperatures [5].

The focus of this paper was to predict heat release rates of fully-developed fires inside of railcars and to evaluate the impact of different variables on the heat release rates. Variables included in the simulations were railcar type, initial number of doors open, time of window fallout, and fire properties of interior finish materials. Modeling could not be conducted on the railcars used in the large-scale testing [5] due to insufficient information the interior finish materials and window failure times. Reference [5] provided the fuel load and heat of combustion of the interior finish materials, but it did not contain cone calorimeter data, heat of gasification data, or surface areas for the interior finish materials. Modeling was, therefore, conducted on generic intercity and subway type railcars with railcar interior finish data from the literature.

\section{RAILCAR DESCRIPTIONS}

Analysis was conducted on both an intercity and a subway type railcar. The layouts of the two railcars are shown in Figs. 2 and 3. The intercity railcar shown in Fig. 2 is approximately $10 \mathrm{~m}$ longer than the subway railcar in Fig. 3. The intercity railcar contained four $0.76 \mathrm{~m}$ wide, $1.91 \mathrm{~m}$ high side doors and twenty-four $0.60 \mathrm{~m}$ high, $1.37 \mathrm{~m}$ long polycarbonate windows. The subway car had four $1.37 \mathrm{~m}$ wide, $2.2 \mathrm{~m}$ high side doors and ten $0.60 \mathrm{~m}$ high, $1.37 \mathrm{~m}$ long polycarbonate windows. Both types of railcars

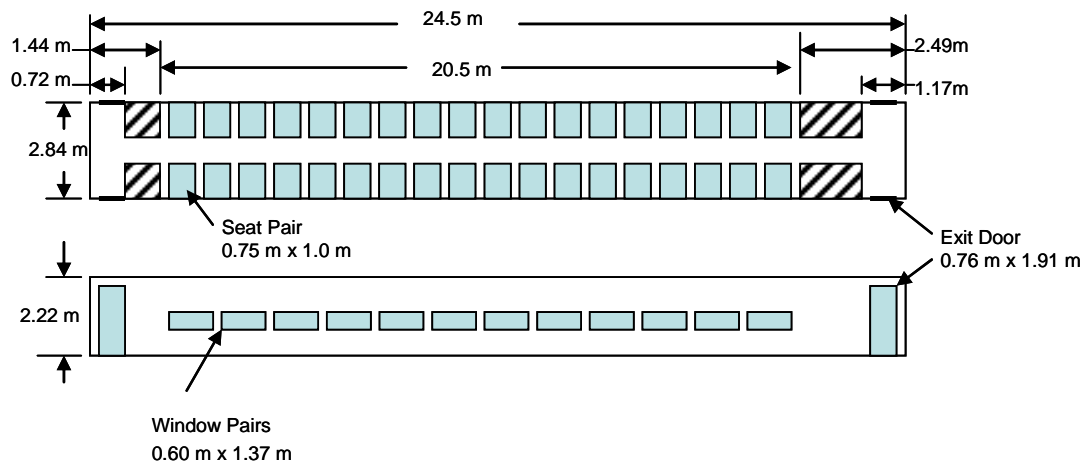

Fig. 2. Intercity railcar layout.

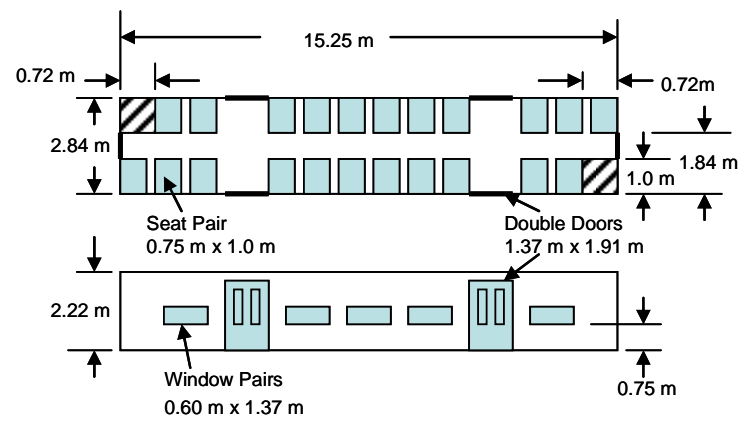

Fig. 3. Subway railcar layout. 
were assumed to have boundaries insulated with $0.076 \mathrm{~m}$ thick layer of glass insulation. Insulation was assumed to have a density of $28 \mathrm{~kg} / \mathrm{m}^{3}$, a conductivity of $0.000038 \mathrm{~kW} / \mathrm{m}$ ${ }^{\circ} \mathrm{C}$, and a specific heat capacity of $0.835 \mathrm{~kJ} / \mathrm{kg}^{\circ}{ }^{\circ} \mathrm{C}[6]$.

\section{Interior Finish and Seating Materials}

The primary fuel source for the railcar fires was the interior finish materials. The types and surface areas of materials were motivated by information in Refs. [7,8]. Tables 1 and 2 provide a description of the interior finish materials on the intercity and subway railcars, respectively. Fire performance data was measured using the cone calorimeter at $50 \mathrm{~kW} / \mathrm{m}^{2}$ [8]. The heat of gasification was determined from

$$
\Delta h_{g}=\frac{\left(q_{h}^{\prime \prime}+q_{f l}^{\prime \prime}-q_{r r}^{\prime \prime}\right)}{\left(\overline{Q^{\prime \prime}} / \Delta H_{c}\right)}=\frac{\left\lfloor 65-\varepsilon_{s} \sigma\left(T_{p y r o l}^{4}-T_{h f g}^{4}\right)-h_{\text {conv }}\left(T_{p y r o l}-T_{h f g}\right)\right\rfloor}{\left(\overline{Q^{\prime \prime}} / \Delta H_{c}\right)}
$$

where the flame heat flux was taken as $15 \mathrm{~kW} / \mathrm{m}^{2}$ [9]. Spearpoint and Quintiere [10] measured the surface temperature of wood during pyrolysis to increase with imposed heat flux and determined it was close to the steady-state surface temperature. The surface temperature during pyrolysis was taken to be $50^{\circ} \mathrm{C}$ less than the steady-state temperature due to the imposed heat flux. The steady-state surface temperature was determined from

$$
q_{h f g}^{\prime \prime}=\varepsilon_{s} \sigma\left(T_{s s}^{4}-T_{h f g}^{4}\right)+h_{\text {conv }}\left(T_{s s}-T_{h f g}\right)
$$

Assuming a heat flux of $65 \mathrm{~kW} / \mathrm{m}^{2}$, surface emissivity 0.90 , heat transfer coefficient of $0.01 \mathrm{~kW} / \mathrm{m}^{2}-\mathrm{K}$, and $T_{h f g}=27^{\circ} \mathrm{C}$, the surface temperature during pyrolysis was calculated to be $709^{\circ} \mathrm{C}$ for all railcar interior finish materials.

\begin{tabular}{|c|c|c|c|c|c|c|c|}
\hline \multirow[b]{2}{*}{ Description } & \multirow{2}{*}{$\begin{array}{c}\text { Area } \\
\left(\mathrm{m}^{2}\right)\end{array}$} & \multicolumn{2}{|c|}{ Combustible } & \multirow{2}{*}{$\begin{array}{c}\bar{Q}^{\prime \prime} \\
\left(\mathbf{k W} / \mathbf{m}^{2}\right)\end{array}$} & \multirow{2}{*}{$\begin{array}{c}\text { Total } \\
\text { Heat } \\
\text { Release } \\
\left(\mathbf{k J} / \mathbf{m}^{2}\right)\end{array}$} & \multirow{2}{*}{$\begin{array}{c}\Delta H_{c} \\
(\mathrm{~kJ} / \mathrm{kg})\end{array}$} & \multirow{2}{*}{$\begin{array}{c}\Delta h_{g} \\
(\mathrm{~kJ} / \mathrm{kg})\end{array}$} \\
\hline & & $\begin{array}{c}f \\
(--)\end{array}$ & $\begin{array}{c}\text { Load } \\
\left(\mathrm{kg} / \mathrm{m}^{2}\right)\end{array}$ & & & & \\
\hline Seat & 63.0 & 0.19 & 1.43 & 129 & 9,100 & 11,800 & 1,019 \\
\hline Seat Shroud & 52.2 & 0.73 & 3.21 & 116 & 121,500 & 20,100 & 1,930 \\
\hline Floor Carpet & 58.2 & 0.60 & 0.92 & 111 & 17,800 & 17,100 & 1,716 \\
\hline Wall Carpet & 23.0 & 0.76 & 2.29 & 270 & 76,700 & 29,600 & 1,221 \\
\hline $\begin{array}{l}\text { Window } \\
\text { Mask }\end{array}$ & 9.0 & 0.44 & 1.99 & 92 & 92,000 & 9,960 & 1,206 \\
\hline Window & 19.7 & 0.70 & 10.36 & 116 & 247,000 & 21,050 & 2,021 \\
\hline Wall Lining & 55.0 & 0.76 & 1.68 & 78 & 21,800 & 11,400 & 1,628 \\
\hline $\begin{array}{l}\text { Ceiling } \\
\text { Lining }\end{array}$ & 65.3 & 0.76 & 1.68 & 78 & 21,800 & 11,400 & 1,628 \\
\hline $\begin{array}{l}\text { Window } \\
\text { Drape }\end{array}$ & 60.0 & 0.21 & 0.32 & 168 & 5,350 & 14,600 & 968 \\
\hline
\end{tabular}

Table 1. Interior finish materials on the intercity railcar. 
Table 2. Interior finish materials on the subway railcar.

\begin{tabular}{|c|c|c|c|c|c|c|c|}
\hline \multirow[b]{2}{*}{ Description } & \multirow{2}{*}{$\begin{array}{c}\text { Area } \\
\left(\mathbf{m}^{2}\right)\end{array}$} & \multicolumn{2}{|c|}{ Combustible } & \multirow{2}{*}{$\begin{array}{c}\bar{Q}^{\prime \prime} \\
\left(\mathbf{k W} / \mathbf{m}^{2}\right)\end{array}$} & \multirow{2}{*}{$\begin{array}{c}\text { Total } \\
\text { Heat } \\
\text { Release } \\
\left(\mathbf{k J} / \mathbf{m}^{2}\right)\end{array}$} & \multirow{2}{*}{$\begin{array}{c}\Delta H_{c} \\
(\mathrm{~kJ} / \mathrm{kg})\end{array}$} & \multirow{2}{*}{$\begin{array}{c}\Delta h_{g} \\
(\mathrm{~kJ} / \mathrm{kg})\end{array}$} \\
\hline & & $\begin{array}{c}f \\
(--)\end{array}$ & $\begin{array}{c}\text { Load } \\
\left(\mathrm{kg} / \mathrm{m}^{2}\right)\end{array}$ & & & & \\
\hline Seating & 44.6 & 0.19 & 1.43 & 129 & 9,100 & 11,800 & 1,019 \\
\hline Seat Shroud & 26.4 & 0.73 & 3.21 & 116 & 121,500 & 20,100 & 1,930 \\
\hline Wall Lining & 26.7 & 0.76 & 1.68 & 78 & 21,800 & 11,400 & 1,628 \\
\hline Windows & 11.5 & 0.70 & 10.36 & 116 & 246,900 & 21,050 & 2,021 \\
\hline $\begin{array}{l}\text { Ceiling } \\
\text { Lining }\end{array}$ & 41.9 & 0.76 & 1.68 & 78 & 21,800 & 11,400 & 1,628 \\
\hline $\begin{array}{l}\text { Flooring- } \\
\text { Rubber }\end{array}$ & 41.9 & 0.40 & 7.89 & 92 & 190,000 & 11,000 & 1,332 \\
\hline
\end{tabular}

POST-FLASHOVER FIRE MODEL

\section{Theory}

A one-layer post-flashover model was used to predict the heat release rate of the railcar fire. As proposed in other analyses on post-flashover fires [11,12], an energy balance on a control volume around the compartment as shown in Fig. 4 can be used to predict the gas temperature inside the compartment. Assuming the post-flashover compartment fire is a quasi-steady state process, the governing equations for mass and energy, respectively, are

$\dot{m}_{o}=\dot{m}_{i}+\dot{m}_{f}$

$Q=q_{\text {bound }}+q_{\text {vent }}+q_{\text {pyrol }}-\dot{m}_{i} h_{i}-\dot{m}_{f} h_{f}+\dot{m}_{o} h_{o}$

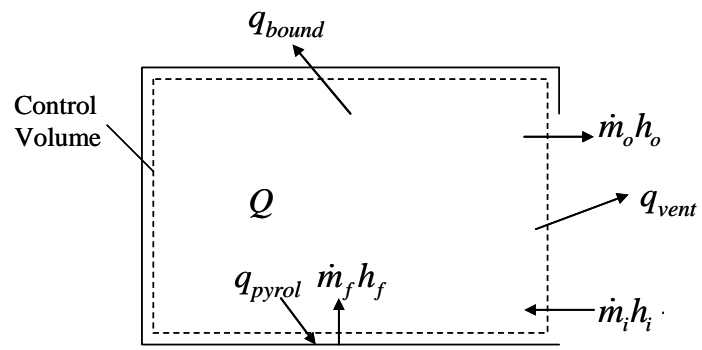

Fig. 4. Energy balance on compartment control volume.

The boundary heat losses were estimated assuming the boundaries behaved as a semiinfinite solid,

$q_{\text {bound }}=\sqrt{\frac{\pi}{4} \frac{k \rho C}{t}} A_{\text {bound }}\left(T-T_{i}\right)$ 
where $T$ is the gas temperature inside the compartment. The radiation losses through the vent were calculated from

$$
q_{\text {vent }}=\varepsilon_{\text {gas }} A_{\text {vent }} \sigma\left(T^{4}-T_{i}^{4}\right)
$$

The energy loss due to pyrolyzing the material was determined using the following relation,

$q_{\text {pyrol }}=\sum_{j=1}^{n} \dot{m}_{f, j} \Delta h_{g, j}$

The specific heat capacity of the incoming air was assumed to be constant at $C_{p, a i r}=1.0$ $\mathrm{kJ} / \mathrm{kg}-\mathrm{K}$, making the enthalpy of the incoming air,

$$
h_{i}=C_{p, \text { air }}\left(T_{i}-T_{\text {ref }}\right)
$$

The specific heat capacity of the fuel from the burning material was assumed to vary with temperature. The enthalpy of the fuel was calculated from

$$
h_{f}=\int_{T_{r e f}}^{T} C_{p, f} d T
$$

The specific heat capacity was taken to be that of propane [13], which has a specific heat capacity that is representative of hydrocarbons and many other fuels. In order to determine the enthalpy of the outgoing gases, the enthalpy of the hot gas mixture was calculated as follows

$$
h_{o}=Y_{\text {air }} C_{p, a i r}\left(T-T_{\text {ref }}\right)+Y_{f} h_{f}
$$

As seen in the above equation, each enthalpy is scaled using the mass fraction of the component in the outgoing stream. The mass flow rate of fuel leaving the compartment was determined by subtracting the fuel burned inside the compartment from the total fuel pyrolyzed.

The mass loss rate of each fuel was predicted from the following equation

$$
\dot{m}_{f, j}=\frac{A_{j} \varepsilon_{s} \sigma\left(\varepsilon_{\text {gas }} T^{4}-T_{\text {pyrol }}^{4}\right)+A_{j} h_{\text {conv }}\left(T-T_{\text {pyrol }}\right)}{\Delta h_{g, j}}
$$

For charring fuels, the pyrolysis temperature was assumed to be $50^{\circ} \mathrm{C}$ less than the steady-state surface temperature for the imposed heat flux. The steady-state temperature 
was determined by setting the net heat flux into the material equal to zero and iteratively solving for the steady-state temperature,

$0=\varepsilon_{s} \sigma\left(\varepsilon_{\text {gas }} T^{4}-T_{s s}^{4}\right)+h_{\text {conv }}\left(T-T_{\text {ss }}\right)$

where, $T_{\text {pyrol }}=T_{s s}-50$. In the decay stage, the fire was assumed to produce a gas temperature of $542^{\circ} \mathrm{C}$ to simulate the heat flux due to a local wall or ceiling fire $\left(\sim 25 \mathrm{~kW} / \mathrm{m}^{2}\right)$.

The heat release rate of the fire was the minimum of the heat release rate of the pyrolyzed fuel and the heat release rate that the air into the compartment could support,

$Q=\min \left[\sum_{j=1}^{n} \chi \dot{m}_{f, j} \Delta H_{c}, \chi 3000 \dot{m}_{j}\right]$

The combustion efficiency, $\chi$, accounts for how well the air mixes and reacts with the fuel. The equivalence ratio of the fire was calculated from

$\phi=\left(\dot{m}_{f} / \dot{m}_{\text {air }}\right) r$

where,

$r=\frac{\left(Q_{\text {total }} / \dot{m}_{f}\right)}{3000}$

\section{Validation}

This model was validated against gas temperature and mass loss rate data from twelve post-flashover fire tests using three different fuels [14]. The compartment was $2 \mathrm{~m}$ wide, $1 \mathrm{~m}$ high, and $1 \mathrm{~m}$ deep with boundaries constructed of $12 \mathrm{~mm}$ thick asbestos board and $6 \mathrm{~mm}$ thick ceramic fiber board. Calculations were performed using $18 \mathrm{~mm}$ thick boundaries and ceramic fiber board thermal properties of $k=0.00010 \mathrm{~kW} / \mathrm{m}-{ }^{\circ} \mathrm{C}$, $C=1.0 \mathrm{~kJ} / \mathrm{kg}-{ }^{\circ} \mathrm{C}$, and $\rho=240 \mathrm{~kg} / \mathrm{m}^{3}$ [15]. Results of the validation are provided in Table 3 using a gas layer emissivity of 0.80 and combustion efficiency of 0.70 . These values provided the best agreement between the model and the data. The gas emissivity is less than 1.0 due to the scale of the experiment. The model was determined to agree to within $\pm 15 \%$ of the gas temperature data and within $\pm 30 \%$ of the mass loss rate data. 
Table 3. Validation of post-flashover fire model.

\begin{tabular}{|c|c|c|c|c|c|c|c|c|}
\hline \multirow[b]{2}{*}{ Fuel } & \multirow{2}{*}{$\begin{array}{l}A H^{1 / 2} \\
\left(m^{5 / 2}\right)\end{array}$} & \multirow{2}{*}{$\begin{array}{l}\text { Fuel } \\
\text { Area } \\
\left(\mathbf{m}^{2}\right)\end{array}$} & \multirow{2}{*}{$\begin{array}{c}\Delta \mathbf{H}_{\mathrm{c}} \\
{[13]} \\
(\mathbf{k J} / \mathbf{k g})\end{array}$} & \multirow{2}{*}{$\begin{array}{c}\Delta \mathbf{h}_{\mathrm{g}} \\
{[11]} \\
(\mathbf{k J} / \mathbf{k g})\end{array}$} & \multicolumn{2}{|c|}{ Data [11] } & \multicolumn{2}{|c|}{ Model } \\
\hline & & & & & $\begin{array}{c}\left(T-T_{i}\right) \\
\left({ }^{\circ} \mathrm{C}\right)\end{array}$ & $\begin{array}{l}\dot{m}_{f} \\
(\mathrm{~g} / \mathrm{s})\end{array}$ & $\begin{array}{c}\left(T-T_{i}\right) \\
\left({ }^{\circ} \mathrm{C}\right)\end{array}$ & $\begin{array}{c}\dot{m}_{f} \\
(\mathbf{g} / \mathbf{s})\end{array}$ \\
\hline Ethanol & 0.25 & 0.186 & 26,800 & 850 & 880 & 19.0 & 875 & 18.7 \\
\hline Ethanol & 0.25 & 0.372 & 26,800 & 850 & 780 & 30.0 & 795 & 28.7 \\
\hline Ethanol & 0.5 & 0.186 & 26,800 & 850 & 1060 & 26.0 & 1044 & 31.2 \\
\hline Ethanol & 0.5 & 0.372 & 26,800 & 850 & 950 & 42.0 & 928 & 44.4 \\
\hline Polyethylene & 0.25 & 0.186 & 38,400 & 2,200 & 980 & 10.0 & 1041 & 10.9 \\
\hline Polyethylene & 0.25 & 0.372 & 38,400 & 2,200 & 910 & 14.0 & 934 & 15.5 \\
\hline Polyethylene & 0.5 & 0.186 & 38,400 & 2,200 & NFO & NFO & NFO & NFO \\
\hline Polyethylene & 0.5 & 0.372 & 38,400 & 2,200 & 1150 & 26.0 & 1077 & 24.4 \\
\hline PMMA & 0.25 & 0.186 & 24,200 & 1,600 & 910 & 12.0 & 1053 & 16.0 \\
\hline PMMA & 0.25 & 0.372 & 24,200 & 1,600 & 820 & 21.0 & 913 & 20.5 \\
\hline PMMA & 0.5 & 0.186 & 24,200 & 1,600 & NFO & NFO & NFO & NFO \\
\hline PMMA & 0.5 & 0.372 & 24,200 & 1,600 & 1030 & 31.0 & 1071 & 33.8 \\
\hline
\end{tabular}

NFO=No Flashover

\section{RAILCAR MODELING RESULTS}

The post-flashover fire model was used to predict the heat release rate and gas temperatures of fires inside of the intercity and subway railcars. In these simulations, the combustion efficiency was 0.70 . Due to the large scale of the railcar, the gas emissivity was increased from the 0.80 value used in the validation to 0.90 . Increasing the gas emissivity will decrease gas temperatures but increase fuel mass loss rate. A summary of the simulation scenarios is provided in Table 4.

Table 4. Summary of simulations on railcars.

\begin{tabular}{|c|c|c|c|c|c|c|}
\hline \multirow{2}{*}{ No. } & \multirow{2}{*}{$\begin{array}{c}\text { Railcar } \\
\text { Type }\end{array}$} & \multirow{2}{*}{ Doors Open } & \multicolumn{2}{|c|}{$\begin{array}{c}\text { Window Fallout } \\
\text { (min) }\end{array}$} & \multicolumn{2}{|c|}{$\mathbf{A}_{\text {bound }} /\left(\mathbf{A H}^{1 / 2}\right)$} \\
\cline { 4 - 7 } & & Start & End & Doors Only & $\begin{array}{c}\text { Doors and } \\
\text { Windows }\end{array}$ \\
\hline 1 & Intercity & 1 & 12.2 & 13.3 & 134.4 & 9.2 \\
\hline 2 & Intercity & 1 & 6.3 & 7.5 & 134.4 & 9.2 \\
\hline 3 & Intercity & 2 & 12.2 & 13.3 & 67.2 & 8.6 \\
\hline 4 & Intercity & 2 & 6.3 & 7.5 & 67.2 & 8.6 \\
\hline 5 & Subway & 1 & 12.2 & 13.3 & 45.3 & 11.0 \\
\hline 6 & Subway & 1 & 6.3 & 7.5 & 45.3 & 11.0 \\
\hline 7 & Subway & 2 & 12.2 & 13.3 & 22.7 & 8.8 \\
\hline 8 & Subway & 2 & 6.3 & 7.5 & 22.7 & 8.8 \\
\hline 8 & Subway & 1 & 0.0 & 1.2 & 45.3 & 11.0 \\
\hline
\end{tabular}

For each railcar, the model was used to evaluate the impact of the number of doors initially open and the time that the polycarbonate windows fallout. Window fallout times were taken from test data on $0.0125 \mathrm{~m}$ thick polycarbonate windows exposed to a line fire that produced a heat flux of $25-30 \mathrm{~kW} / \mathrm{m}^{2}$ [17]. Window fallout times of $6 \mathrm{~min}$. were 
consistent with the entire window being constructed of a single sheet of polycarbonate, $0.60 \mathrm{~m}$ high and $1.37 \mathrm{~m}$ wide. In scenarios with the $12 \mathrm{~min}$. window fallout times, the windows were made of two smaller $(0.60 \mathrm{~m}$ high and $0.68 \mathrm{~m}$ wide) sheets of polycarbonate reinforced in the center of the window.

The predicted heat release rate and gas temperature inside of the intercity railcar are provided in Fig. 5. Peak heat release rates ranged from 19-41 MW while peak gas temperatures were $1100^{\circ} \mathrm{C}$. Changes in heat release rate and temperature at 6 and 12 minutes were due to the windows falling out. Other abrupt changes in the heat release rate were due to the complete consumption of the combustible fraction (burning out) of different materials within the railcar. Initially having one door open allowed the heat release rate prior to window fallout to be approximately half that when two doors were initially open. The result of this is that less fuel was consumed prior to window fallout in the case with one door open. When windows did fallout, the heat release rate was able to increase more in the cases with one door initially open because there was fuel available to support the larger fires. With two doors initially open and a window fallout time of 12 minutes, no significant increase was predicted at window fallout due to all but two of the materials burning out before the windows fell out.
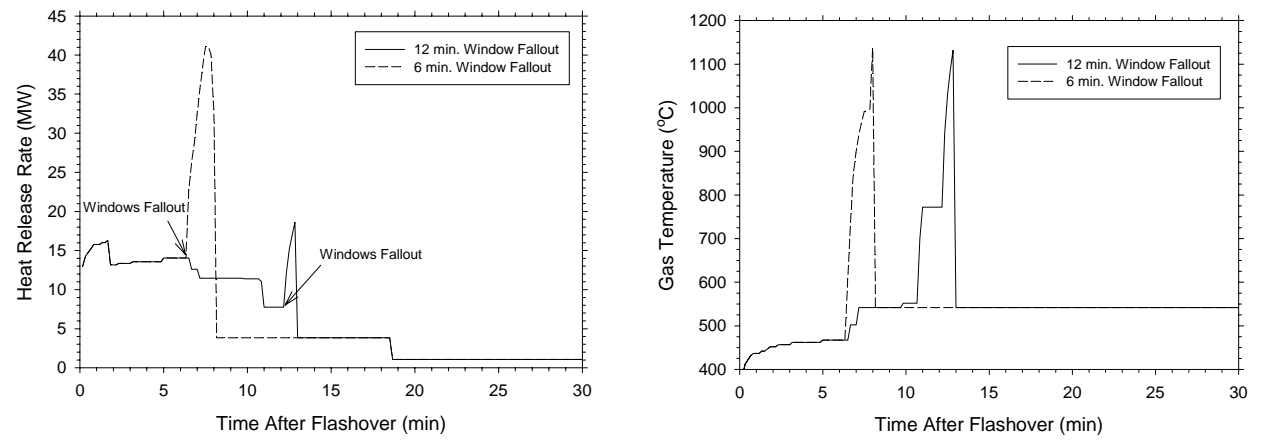

(a) One Door Initially Open
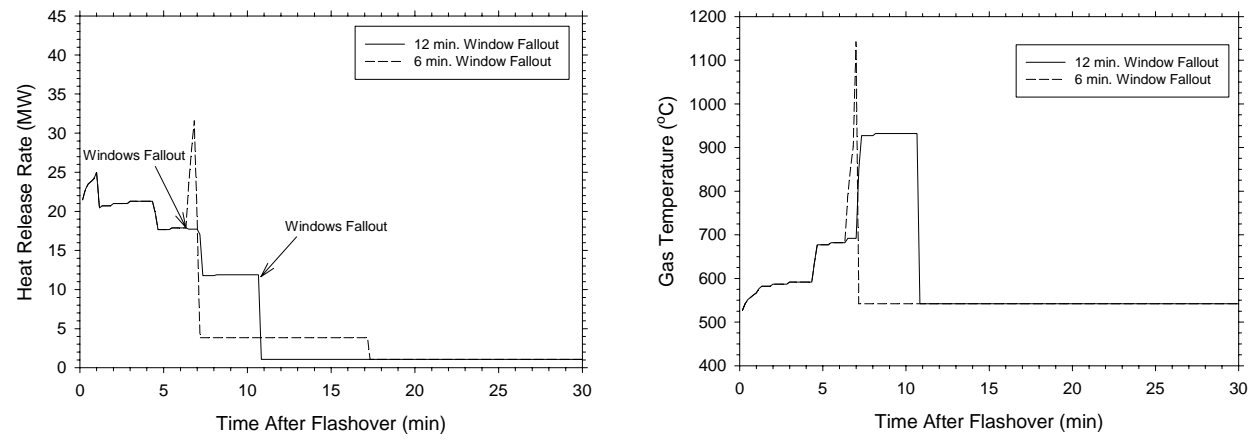

(b) Two Doors Initially Open

Fig. 5. Intercity railcar modeling results.

Results for the simulations on the subway railcar are provided in Fig. 6. The peak heat release rates were $14-22 \mathrm{MW}$ with peak gas temperatures of $1100^{\circ} \mathrm{C}$. The impact of the window fallout was not as pronounced in these simulations compared with the intercity railcar results. This was attributed to both less interior finish material inside these cars 
and the larger door sizes. The larger door size increased the gas temperatures prior to window fallout, increasing the rate of consumption of the materials prior to window fallout. As a result, higher heat release rates could not be supported after window fallout.
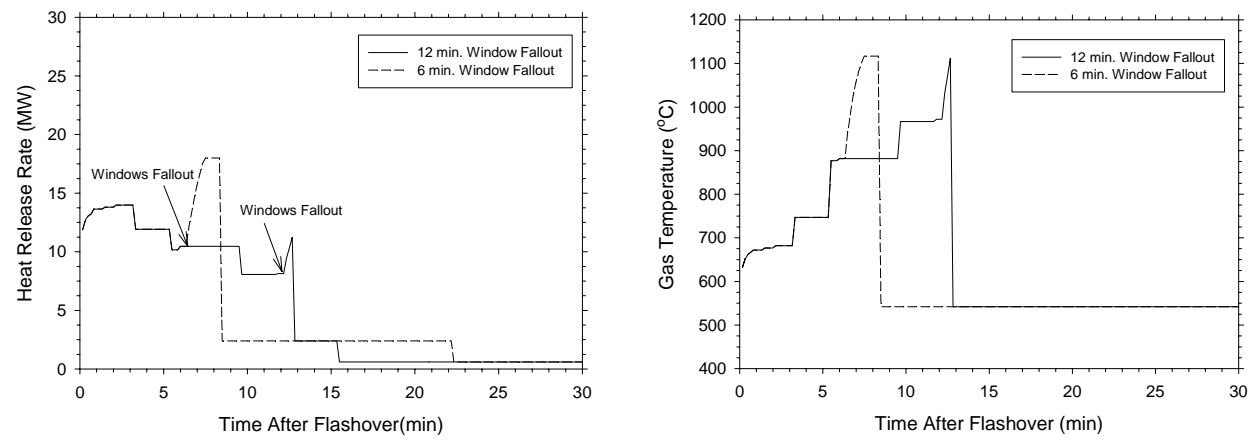

(a) One Door Initially Open
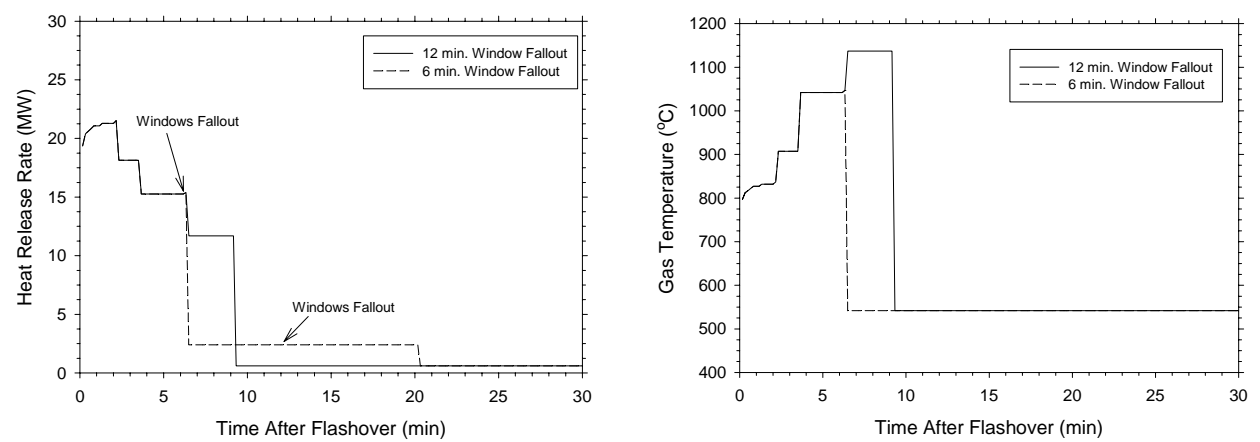

(b) Two Doors Initially Open

Fig. 6. Subway railcar modeling results.

Results from simulations in Figs. 5 and 6 indicate that faster window fallout can result in a significant increase in heat release rate if fuel was available to support a larger fire. One limit of this would be if windows fell out at the onset of flashover and all fuels have a combustible fraction of $100 \%$. Figure 7 contains a plot of the heat release rate and gas temperature inside of the subway type railcar under these limiting conditions with one door initially open. As expected, the magnitude of the heat release rate in Fig. 7 bounds the peak heat release rates in Fig. 6a where one door was initially open. The decrease in heat release rate at 5 minutes was due to the wall and ceiling linings burning out. Increases in gas temperature at 5 and 8 minutes were due to materials burning out causing the equivalence ratio to become closer to stoichiometric ( $\phi=1.4$ at $5 \mathrm{~min}$. and $\phi=1.0$ at $8 \mathrm{~min}$.). This indicates that a higher heat release rate for this railcar could be possible if the conditions at the onset of flashover were closer to stoichiometric. If the railcar is placed inside of a tunnel, the heat release rate may be even higher due to tunnel ventilation effects and heat feedback from the tunnel surroundings [18]. 

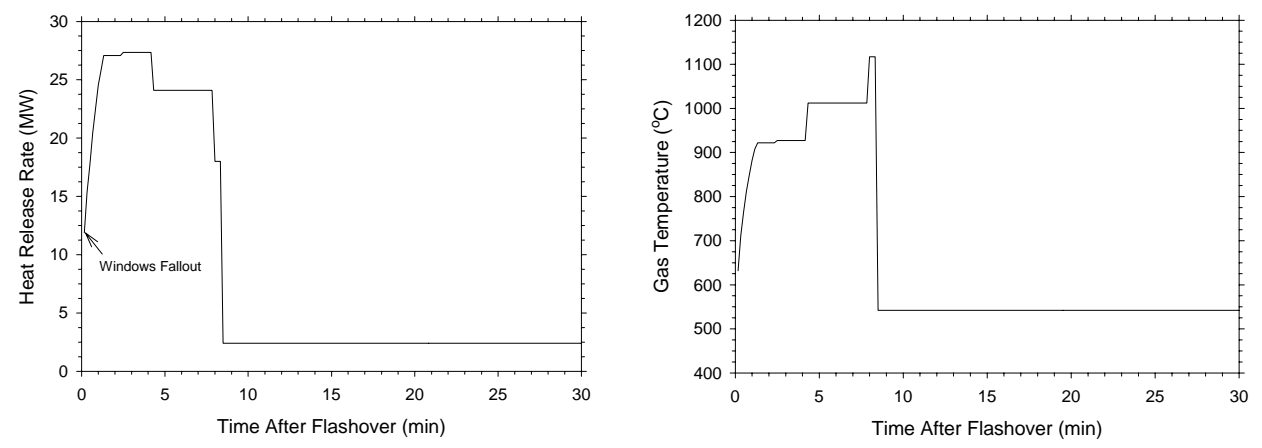

Fig. 7. Subway railcar with one door initially open and window fallout at flashover.

\section{CONCLUSIONS}

The heat release rate history of fully-developed fires inside of railcars is dependent on the fire properties of interior finish materials, the surface area and combustible mass of fuel inside of the railcar, and the ventilation conditions into the railcar. The post-flashover fire model predicted gas temperatures and heat release rates similar in magnitude to levels measured in large-scale fire tests on railcars. Window fallout was predicted to result in a large increase (3-27 MW) in heat release rate, if sufficient fuel is available to support larger fires. Similar abrupt changes in gas temperature and heat release rate were measured in large-scale testing when windows failed. Bounding heat release rate histories can be developed by assuming windows fallout at the onset of flashover with ventilation conditions that result in a compartment fire that is close to stoichiometric.

Some trends in the modeling did not agree with large-scale test data. Modeling results indicate that the larger intercity railcars with more interior finish material resulted in higher heat release rates compared with the smaller subway railcars. The opposite trend was measured in large-scale testing. The reason for the differences may be due to when glass windows shattered in the tests versus the polycarbonate window fallout times in the modeling. Future large-scale test programs on railcars need to report cone calorimeter test data on interior finish materials, surface area of each interior finish material, occurrence of window fallout, and size of ventilation openings during the test. Prior to testing, simulations should also be conducted to determine the ventilation conditions that will result in the worst-case heat release rate for the railcar.

\section{REFERENCES}

[1] NFPA 130, "Standard for Fixed Guideway Transit and Passenger Rail Systems," National Fire Protection Association, Quincy, MA, 2003.

[2] Ingason, H., “Design Fires in Tunnels," ASIAFLAM '95, Interscience Communications, 1995, pp.77-86.

[3] Steinert, C., "Smoke and Heat Production in Tunnel Fires," International Conference on Fires in Tunnels, Swedish National Testing and Research Institute, 1994, pp. 104-122. 
[4] Blume, G., "Smoke and Heat Production in Tunnel Fires - Smoke and Hot Gas Hazards," International Conference on Fires in Tunnels, Swedish National Testing and Research Institute, 1994, pp. 138-146.

[5] EUREKA 1995, "Fires in Transport Tunnels - Report on Full-Scale Tests," EUREKA Project EU 499:FIRETUN, Studiengesellschaft Stahlanwendung e.V., D-40213 Dusseldorf, 1995.

[6] Incopera, F., and Dewitt, D., Fundamentals of Heat and Mass Transfer, $3^{\text {rd }}$ Edition, John Wiley and Sons, 1990.

[7] Peacock, R, Bukowski, R., Reneke, P., Averill, J., and Markos, S., "Fire Safety of Passenger Trains, Phase II: Application of Fire Hazard Analysis Techniques," U.S. Department of Transportation Report DOT/FRA/ORD-01/16, Washington, DC, 2001, 180p.

[8] Peacock, R., and Braun, E., "Fire Safety on Passenger Trains, Phase I: Material Evaluation (Cone Calorimeter)," U.S. Department of Transportation Report DOT/FRA/ORD-99/01, Washington, D.C., 1999, pp. 196.

[9] Ritchie, S., Steckler, K., Hamins, A., Cleary, T., Yang, J., and Kashiwagi, T., Fire Safety Science-Proceedings of the Fifth International Symposium, International Association for Fire Safety Science, 1997, pp.177-188.

[10] Spearpoint, M.J., and Quintiere, J.G., "Predicting the Burning of Wood Using an Integral Model,” Combustion and Flame, 123, pp. 308-324, (2000).

[11] Babrauskas, V. and Wickstrom, U., "Thermoplastic Pool Compartment Fires," Combustion and Flame, 34, pp. 195-201, (1979).

[12] SFPE, Engineering Guide on Fire Exposures to Structural Elements, Society of Fire Protection Engineers, 2004, pp. 151.

[13] Van Wylen and Sonttag, Introduction to Thermodynamics, John Wiley and Sons, 1986, pp. 749.

[14] Bullen, M., and Thomas, P., "Compartment Fires with Non-Cellulosic Fuels," $17^{\text {th }}$ International Symposium on Combustion, The Combustion Institute, 1978, pp. 1139-1148.

[15] Unifrax, personal communication, 2002.

[16] Tewarson, A., "Generation of Heat and Chemical Compounds in Fires," The SFPE Handbook of Fire Protection Engineering ( $\left.3^{r d} e d\right)$, DiNenno P.J. (ed.), National Fire Protection Association, Quincy, MA 02269, 2002, pp. 3-82.

[17] Strege, S., Lattimer, B., and Beyler C., "Fire Induced Failure of Polycarbonate Windows in Railcars," Fire and Materials, 2003, pp. 269-278.

[18] Ingason, H., "Fire Dynamics in Tunnels," The Handbook of Tunnel Fire Safety, Eds. Beard and Carvel, Thomas Telford, Ltd., 2005. 